\title{
ENDOMETRIAL POLYPS AND MICROPOLYPS. MICROBIAL LANDSCAPE OF THE UTERINE CAVITY AND ITS ROLE IN THEIR FORMATION
}

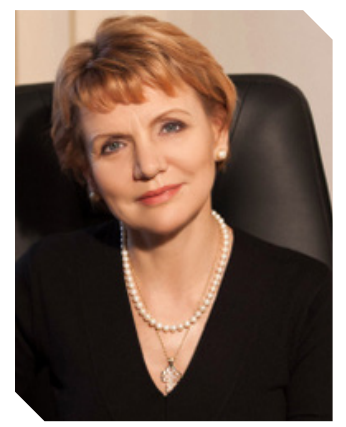

T.F. TATARCHUK

MD, professor, corresponding member of the HAMS of Ukraine, deputy

director for research work, chief of the Endocrine Gynecology Department, SI "Institute of Pediatrics,

Obstetrics and Gynecology of the NAMS of Ukraine"

ORCID: 0000-0002-5498-4143

\section{D.G. HERMAN}

postgraduate student at the Endocrine Gynecology Department,

SI "Institute of Pediatrics,

Obstetrics and Gynecology of the NAMS of Ukraine"

ORCID: 0000-0002-9043-9214

\section{Contacts:}

Tetiana F. Tatarchuk

SI "Institute of Pediatrics,

Obstetrics and Gynecology of

the NAMS of Ukraine", Endocrine

Gynecology Department

Maiborody P. str. 8,

04050, Kyiv, Ukraine

phone: +38 (044) 4838087 ;

+38 (044) 2721072

e-mail: ipag.gyn@femina-health.org

\section{INTRODUCTION}

Nowadays the value of each pregnancy is increasing drastically with infertility becoming an extremely acute problem, often provoked by an intrauterine pathology. Nobody today will dispute the feasibility of a hysteroscopic study of women with infertility.

The results of one of the largest studies on the subject were very convincing. It collected data from 1000 patients who were preparing for ART programs and did not have clinical manifestations of intrauterine process. All women had a one-step colpo-cervical hysteroscopy. As a result, more than one-third (38\%) of women demonstrated various intrauterine formations, moreover some of them had more than one. Consequently, every third woman (32\%) was diagnosed with polyps of different sizes, $3 \%$ had submucous fibroids and the same number of women had adhesions [1].

\section{ANALYSIS OF PUBLISHED DATA AND \\ FORMULATION OF RESEARCH TASK}

Today, endometrial polyps (EP) are the most common "structural abnormalities" of endometrium, among those that cause unexplained infertility [2]. The mechanism of their negative impact on fertility is poorly studied, however, there have been a number of assumptions in recent publications. It is generally considered that EP:

- cause a mechanical obstruction for sperm migration, especially if the place of their location are the fallopian tubes;

provide an anatomical obstacle for implantation [3];

increase production of inhibitory factors, such as glycodelin, which are able to oppress functioning of natural killer cells [4];

- reduce secretion of implantation factors such as IGFBP-1, TNF- $a$ and osteopontin [5].

Despite the development of new diagnostic techniques, general agreement on the causes of EP does not exist. There is also no unequivocality in pathogenic aspects. Some researchers believe EP are estrogen dependent tumors arising in conditions involving hyperestrogenemia [6]. Other authors attribute the formation of EP to an imbalance in the expression of estrogen and progesterone receptors [7]. Some declare EP the product of genetic mutations that lead to increased mitosis and reduced apoptosis [8, 9]. But lately, more and more researchers actualize theory of inflammatory origin of EP [10, 11].

Chronic endometritis (CE), which is fraught with the potential of hyperplastic and neoplastic growth, contributes not only to the pathogenesis of benign endometrial changes, but also to the formation of infertility. According to different authors, CE rate in infertile women ranges from 12 to $60 \%$, and in patients with multiple failed IVF attempts exceeds $60 \%$ [12]. Highest frequency indices of CE were observed in patients with recurrent miscarriage, where the disease rate was from $33 \%$ to $70 \%$ or more.

Micropolyps are inextricably linked with the phenomenon of CE. In 2005, E. Cicinelli et al. after numerous hysteroscopic studies identified specific macroscopic aspect: polypoid tumors of the mucous membrane, 1-2 mm, have always accompanied a histologically confirmed diagnosis of CE [13]. Those formations have been described as micropolyps (MP) and referred to the most important hysteroscopic signs of CE.

The fact that MP are formed by the accumulation of inflammatory cells in endometrial stroma, as a consequence of an active and strong inflammatory response, explains the need for further study and comparison with conventional EP. Both of these lesions potentially provide a hostile environment for the receptivity of the endometrium, and thus, may have something in common in their etiopathogenesis.

Thus, endometrial polyps and chronic endometritis are an extremely unfavorable duo, that drastically increases the risk of infertility and requires correction of therapeutic approaches in general.

There is a well-established view of the leading role of the imbalance between the hormonal and immune systems of the body in the genesis of chronic inflammation in the endometrium on one hand, and pathogens on the other. Infectious agent is recognized as a common trigger of the development of an inflammatory process in endometrium. Given the lack of data in a comprehensive study of the mucous membranes of the genital tract in women of reproductive age with $\mathrm{EP}$ and MP, it seems appropriate to examine the role of urogenital infections in the formation of the tumors mentioned above. 
OBJECTIVE: To conduct a comprehensive study of microbiocenosis in women with EP and MP in order to establish new links in the mechanism of their development and further optimization of treatment.

\section{MATERIALS AND METHODS}

The authors carried out a comprehensive clinical and laboratory examination of patients between the ages of 18 and 35 who consulted the Department of Endocrine Gynecology, the State Institution "Institute of Pediatrics, Obstetrics and Gynecology of the NAMS of Ukraine" with the purpose of planning a pregnancy.

After studying their history, holding an ultrasound of the pelvic organs, 30 healthy fertile women of reproductive age were allocated and placed into the control group III. This category of women had no gynecological diseases, did not use intrauterine contraception, had no spontaneous, artificial abortion and history of intrauterine interventions.

All patients with a variety of detected violations of reproductive function (infertility, miscarriage, endometrial polyps) had hysteroscopy. After the analysis of hysteroscopic signs and histopathological study results women were divided into two groups.

Group I consisted of 70 women with endometrial polyps whose EP were suspected during ultrasound, defined during hysteroscopy as a leg protruding formation of the uterine cavity and confirmed histologically.

Group II included 30 women with endometrial MP whose polypoid bulge, 1-2 $\mathrm{mm}$ in size, were first discovered during hysteroscopy and were not revealed at the previously held sonographic study.

According to the literature, a significant discrepancy is possible between the frequency of micropolyps detection during hysteroscopy and their presence in tissue specimens. It is because of their extremely small size that MP may be lost in the process of preparation of histological material [14]. Given that the specificity of the detection of MP with CE is $99 \%$, the MP group included women whose identified through hysteroscopy micropolyps combined with histologically confirmed CE. The accuracy of morphological verification of CE was increased at the expense of mandatory detection of plasma cells using marker CD138.

To exclude the possible presence of concealed CE, patients in the control group had endometrial biopsy with the help of suction curette Pipelle de Cornie on the $7^{\text {th }}-10^{\text {th }}$ day of the menstrual cycle and subsequent morphological and immunohistochemical (CD138) study of the resulting material.

All patients gave written consent to participate in the study. When forming groups, the following exclusion criteria were taken into account: malformations of the sexual organs; severe endocrine pathology; any extragenital diseases in the acute or subacute stage; antiphospholipid syndrome; pregnancy and lactation; malignant tumors of any localization; use of systemic or local antibiotic therapy within the previous three months.

Complex microbiological examination included assessment of vaginal microbiocenosis according to Gram staining microscopy and culture studies of vaginal discharge; study of cervical microflora and biopsy of endometrium in aerobic, microaerophilic and anaerobic culturing conditions.
Bacteriological profile of vaginal contents included research of norm biota (Lactobacillus spp.), aerobic flora (Enterobacteriaceae, Streptococcus spp., Staphylococcus spp.), anaerobic flora (Gardnerella vaginalis, Prevotella bivia, Pophyromonas spp., Eubacterium spp., Sneathia spp., Leptotrihia spp., Fusobacterium spp., Megasphaera spp., Veilonella spp., Dialister spp., Lachnobacterium spp., Clostridium spp., Mobiluncus spp., Corynebacterium spp., Peptostreptococcus spp., Atopobium vaginae, Mycoplasma hominis, Mycoplasma genitalium, Ureaplasma urealiticum, Ureaplasma parvum) and yeast-like fungi of the genus Candida.

"Femoflor" test-system was used in order to obtain the most complete quantitative characterization of normal and conditionally pathogenic flora of the urogenital tract in women studied. Investigation was conducted by the PCR method with result detection in real time (RT-PCR) (sensitivity $88.7 \%$, specificity $89.6 \%)$. In the course of the analysis, relative amount of the respective group of microorganisms was calculated in the total bacterial mass, and later presented in the form of common logarithm. Upon detection of conditionally pathogenic bacteria, indicators $>10^{4}$, and for fungi $>10^{3} \mathrm{CFU} / \mathrm{ml}$ were used as diagnostic titer.

Bacteriological examination of material from the cervical canal was carried out on a traditional scheme. Material collection was done with disposable sterile gynecologic brushes - cervix brush was injected into the cervical canal by $1-1.5 \mathrm{~cm}$ and rotated for 3-5 seconds. After extraction, with avoidance of contact with the vaginal walls, it was placed in a test tube with a disposable sterile transport medium.

To eliminate contamination of endometrial biopsy with microflora of the lower divisions of the genitals, different loci were consistently treated with antiseptic.

To identify potential viruses or bacteria, polymerase chain reaction method was used (PCR). The contents of the cervical canal and the endometrial biopsies of all women in the research were studied for the detection of specific DNA fragments of Chlamydia trachomatis, Mycoplasma hominis, Mycoplasma genitalium, Ureaplasma urealiticum, Ureaplasma parvum, Neisseria gonorrhoeae, Trichomonas vaginalis, Herpes simplex virus type 1, 2 and 6, Cytomegalovirus, Enterovirus, HPV with genotyping.

Microbiological testing of the endometrial biopsies was performed using a culture method in order to identify facultative anaerobic bacteria and fungi.

All studies were performed in "Dila" medical laboratory.

Statistical data processing was carried out using a standard software package "Statistica for Windows" V. 13.0, StatSoft Inc. (USA).

\section{RESULTS OF THE STUDY}

The groups were represented on the basis of age (the average age in group I was $30.2 \pm 4.11$ years, in group II -32.4 \pm 2.57 , in III $-31.0 \pm 2.77$ years, $\mathrm{p}=0.175$ ) and $\mathrm{BMI}$ (the average BMI in the I group $-23.0 \pm 4.10 \mathrm{~kg} / \mathrm{m}^{2}$, in II $-20.9 \pm 2.26 \mathrm{~kg} / \mathrm{m}^{2}$, in III $-21.0 \pm 1.52 \mathrm{~kg} / \mathrm{m}^{2}, \mathrm{p}=0.188$ ).

The average age at menarche in females of group I was 13.1 \pm 1.34 years and did not differ from that in group $\mathrm{II}-13.3 \pm 0.76$ years and in the control group - $13.3 \pm 0.95$ years. The average duration of the menstrual cycle also did not vary significantly, 
and lasted $28.0 \pm 3.02$ days in representatives of group I, group II $-28.1 \pm 1.95$ days, group III $-29.1 \pm 3.58$ days. The median duration of menstruation in group I was 5 days (5-6), in group III - 4 days (4-6). In group II the average duration of menstruation was similar to the comparison groups and was $5.3 \pm 0.95$ days.

The study design was determined by the principle of consistent study of the microflora of different habitats: the vagina, the cervix, the uterus cavity (endometrium).

When assessing the condition of vaginal environment, where the titer of Lactobacillus spp. was below $10^{6}$, lactoflora deficiency was found present in group II of women significantly more often than in groups I and III (30\% vs. $10 \%$ and $3 \%$, respectively) $\left(\mathrm{p}_{\mathrm{I-II}}=0.018, \mathrm{p}_{\mathrm{II-III}}=0.012\right)$.

Presence of a sufficient amount of Lactobacilli (more than 107) was naturally characteristic of healthy women (63\%). Whereas, in cohort with EP and MP significantly lower figures were found (39\% and $23 \%$, respectively) $\left(p_{|-|||}=0.023, p_{||-|| I}=0.004\right)$.

Interestingly, almost half of group I patients (51\%) and group II (47\%) titer of Lactobacillus spp. had borderline significance $10^{6}-10^{7} \mathrm{CFU} / \mathrm{ml}$ (Table 1).

\begin{tabular}{|c|c|c|c|c|}
\hline \multicolumn{5}{|c|}{ Number of Lactobacillus spp. } \\
\hline & & $<10^{6} \mathrm{CFU} / \mathrm{ml}$ & I $10^{6}-10^{7} \mathrm{CFU} / \mathrm{ml}$ & $>10^{7} \mathrm{CFU} / \mathrm{m}$ \\
\hline \multirow{3}{*}{$\begin{array}{l}\text { I group } \\
(n=70)\end{array}$} & Modulus & 7 & 36 & 27 \\
\hline & $\%$ & 10 & 51 & 39 \\
\hline & $95 \% \mathrm{Cl}$ & $4.1-19.5$ & $39.2-63.6$ & $27,2-51,0$ \\
\hline \multirow{3}{*}{$\begin{array}{l}\text { II group } \\
(n=30)\end{array}$} & Modulus & 9 & 14 & 7 \\
\hline & $\%$ & 30 & 47 & 23 \\
\hline & $95 \% \mathrm{Cl}$ & $14.7-49.4$ & $28.3-65.7$ & $9.9-42.3$ \\
\hline \multicolumn{2}{|c|}{ p-value I-II } & $0.018^{c}$ & $0.663^{\mathrm{a}}$ & $0.213^{b}$ \\
\hline \multirow{3}{*}{$\begin{array}{l}\text { III group } \\
(n=30)\end{array}$} & Modulus & 1 & 10 & 19 \\
\hline & $\%$ & 3 & 34 & 63 \\
\hline & $95 \% \mathrm{Cl}$ & $0.1-17.2$ & $17.3-52.8$ & $43.9-80.1$ \\
\hline \multicolumn{2}{|c|}{ p-value I-III } & 0.429 & $0.096^{\mathrm{a}}$ & $0.023^{\mathrm{a}}$ \\
\hline \multicolumn{2}{|c|}{ p-value II-III } & $0.012^{c}$ & $0.292^{\mathrm{a}}$ & $0.004^{b}$ \\
\hline
\end{tabular}

The results of quantitative assessment of the content of pathogens (that exceed $10^{4} \mathrm{CFU} / \mathrm{ml}$ ) in the vagina are presented in Table 2.

It is important to note that no statistically significant differences in the quantitative composition of the vaginal microflora were detected in all groups studied. Group I as well as group II and III shared 3 main pathogens according to the frequency of occurrence: Gardnerella vaginalis, Eubacterium spp. and Ureaplasma spp. The percentage distribution of these microorganisms in a cohort with EP presented the following data: $34 \%, 36 \%$ and $36 \%$, respectively, in a cohort with MP $30 \%, 17 \%$ and $17 \%$, in healthy women $-53 \%, 30 \%$ and $30 \%$.

The range of other infectious microorganisms was also very extensive and similar in all three groups. Streptococcus spp. was found in the vagina of $20 \%$ of women of group I, $17 \%$ - group II, and 29\% - group III. Candida spp. was found in $16 \%$ of the representatives of group I, $3 \%$ - group II, $13 \%$ in healthy women from group III. A detailed analysis of the vaginal microbiocenosis in each of the groups studied is shown in Figure 1.
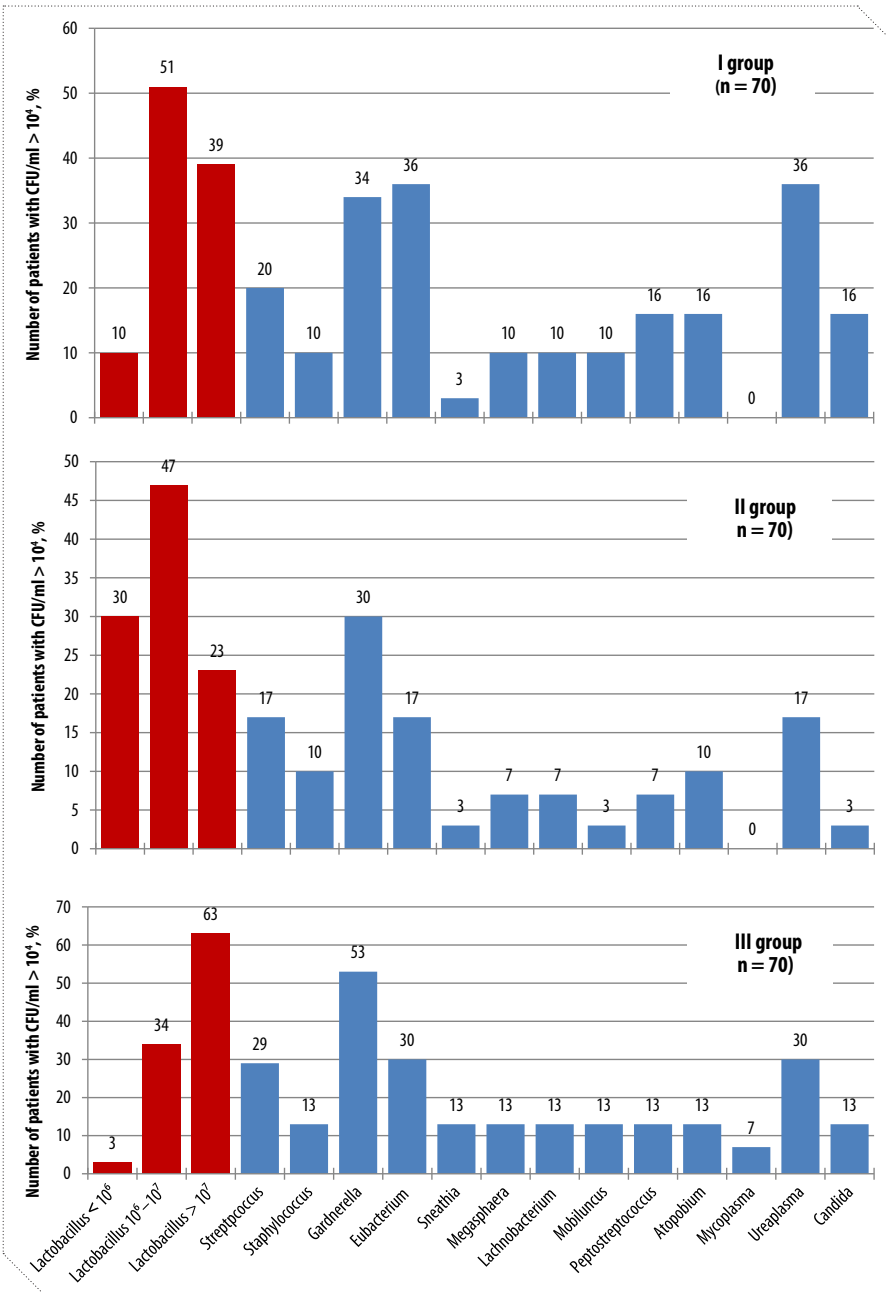

Figure 1. Quantitative composition of the vaginal microflora

Despite the seeming similarity of species composition of the vaginal microflora of representatives from all the groups, the true state of affairs emphasizes the ratio of lactic acid bacteria and the colonies of the pathogen. Thus, out of all the groups represented, only healthy women, who had any infectious microorganisms in amount of $10^{4} \mathrm{CFU} / \mathrm{ml}$ or more, also had a sufficient number of lactobacilli (more than $10^{7}$ ). In cohorts with EP and MP, this ratio changed, and high titers of conditionally pathogenic microorganisms could no longer be balanced out by the normal content of lactobacilli.

Given that the cervix is the first barrier to ascending infection, the next step was to conduct a study of contamination of the cervical canal, the results of which are shown in Table 3.

Analysis of the data showed a relatively high percentage of cervical sterility in all of the groups of women. Growth of microorganisms was not detected in 20 women from group I (29\%), 14 (47\%) from group II and 9 (30\%) from group III.

The spectrum of pathogenic agents isolated from the cervical canal was much narrower, compared with that of the vagina. Ureaplasma was equally often present in the acquired samples $(29 \%-\mathrm{I}, 20 \%-\mathrm{II}, 13 \%$ - III) as well as mycoplasma $(6 \%-I, 7 \%-I I, 13 \%-I I I)$. 
Table 2. Microbiocenosis of the vagina of women from study groups

\begin{tabular}{|c|c|c|c|c|c|c|c|c|c|c|c|c|c|c|}
\hline & 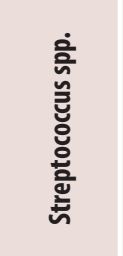 & 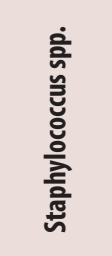 & 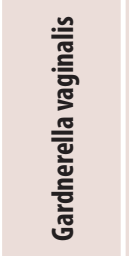 & 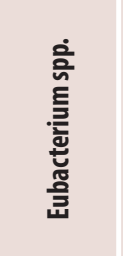 & 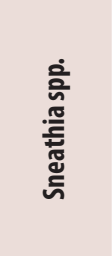 & 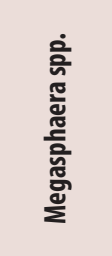 & 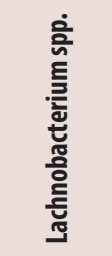 & 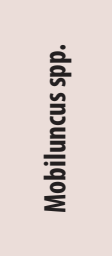 & 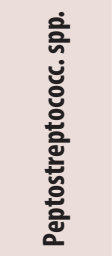 & 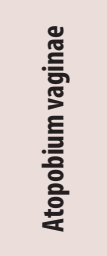 & 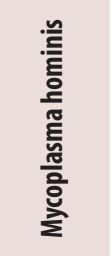 & 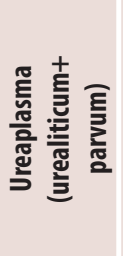 & 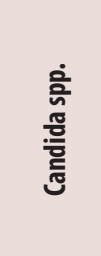 \\
\hline \multirow{3}{*}{$\begin{array}{l}\text { I group } \\
(n=70)\end{array}$} & Modulus & 14 & 7 & 24 & 25 & 2 & 7 & 7 & 7 & 11 & 11 & 0 & 25 & 11 \\
\hline & $\%$ & 20 & 10 & 34 & 36 & 3 & 10 & 10 & 10 & 16 & 16 & 0 & 36 & 16 \\
\hline & $95 \% \mathrm{Cl}$ & $11.4-31.3$ & $4.1-19.5$ & $23.4-46.6$ & $24.6-48.1$ & $0.4-9.3$ & $4.1-19.5$ & $4.1-19.5$ & $4.1-19.5$ & $8.1-26.4$ & $8.1-26.4$ & - & $33.4-38.1$ & $8.1-26.4$ \\
\hline \multirow{3}{*}{$\begin{array}{l}\text { II group } \\
(n=30)\end{array}$} & Modulus & 5 & 3 & 9 & 5 & 1 & 2 & 2 & 1 & 2 & 3 & 0 & 5 & 1 \\
\hline & $\%$ & 17 & 10 & 30 & 17 & 3 & 7 & 7 & 3 & 7 & 10 & 0 & 17 & 3 \\
\hline & $95 \% \mathrm{Cl}$ & $5.6-34.7$ & $2.1-26.5$ & $14.7-49.4$ & $5.6-34.7$ & $0.1-17.2$ & $0.8-22.1$ & $0.8-22.1$ & $0.1-17.2$ & $0.8-22.1$ & $2.1-26.5$ & - & $5.6-34.7$ & $0.1-17.2$ \\
\hline \multicolumn{2}{|c|}{ p-value I-II } & $0.787^{c}$ & $1.000^{c}$ & $0.863^{b}$ & $0.062^{c}$ & $1.000^{c}$ & $0.720^{c}$ & $0.720^{c}$ & $0.429^{c}$ & $0.334^{c}$ & $0.544^{c}$ & $1.000^{c}$ & $0.062^{c}$ & $0.101^{c}$ \\
\hline \multirow{3}{*}{$\begin{array}{l}\text { III group } \\
(n=30)\end{array}$} & Modulus & 8 & 4 & 16 & 9 & 4 & 4 & 4 & 4 & 4 & 4 & 2 & 9 & 4 \\
\hline & $\%$ & 29 & 13 & 53 & 30 & 13 & 13 & 13 & 13 & 13 & 13 & 7 & 30 & 13 \\
\hline & $95 \% \mathrm{Cl}$ & $12.3-45.9$ & $3.8-30.7$ & $34.3-71.7$ & $14.7-49.4$ & $3.8-30.7$ & $3.8-30.7$ & $3.8-30.7$ & $3.8-30.7$ & $3.8-30.7$ & $3.8-30.7$ & $0.8-22.1$ & $14.7-49.4$ & 3.8-30.7 \\
\hline \multicolumn{2}{|c|}{ p-value I-III } & $0.639^{\mathrm{b}}$ & $0.729^{c}$ & $0.075^{a}$ & $0.752^{\mathrm{b}}$ & $0.064^{c}$ & 0.729 & $0.729^{c}$ & $0.729^{c}$ & $1.000^{c}$ & $1.000^{c}$ & $0.088^{c}$ & $0.650^{c}$ & $1.000^{c}$ \\
\hline \multicolumn{2}{|c|}{ p-value II-III } & $0.532^{b}$ & $0.712^{c}$ & $0.116^{b}$ & $0.243^{c}$ & $0.353^{c}$ & $0.433^{c}$ & $0.433^{c}$ & $0.353^{c}$ & $0.433^{c}$ & $1.000^{c}$ & $0.492^{c}$ & $0.243^{c}$ & $0.203^{c}$ \\
\hline
\end{tabular}

Table 3. Microbiocenosis of the cervical canal of women from study groups

\begin{tabular}{|c|c|c|c|c|c|c|c|c|}
\hline & & 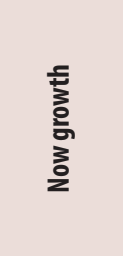 & 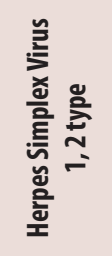 & 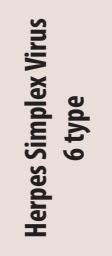 & 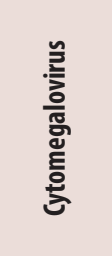 & 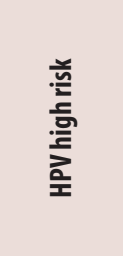 & 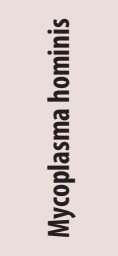 & 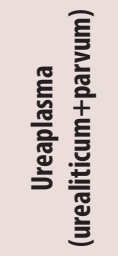 \\
\hline \multirow{3}{*}{$\begin{array}{l}\text { I group } \\
(n=70)\end{array}$} & Modulus & 20 & 0 & 0 & 0 & 22 & 4 & 20 \\
\hline & $\%$ & 29 & 0 & 0 & 0 & 31 & 6 & 29 \\
\hline & $95 \% \mathrm{Cl}$ & $18.4-40.6$ & - & - & - & $20.9-43.6$ & $1.6-14.0$ & $18.4-40.6$ \\
\hline \multirow{3}{*}{$\begin{array}{l}\text { II group } \\
(\mathrm{n}=30)\end{array}$} & Modulus & 14 & 1 & 1 & 2 & 6 & 2 & 6 \\
\hline & $\%$ & 47 & 3 & 3 & 7 & 20 & 7 & 20 \\
\hline & $95 \% \mathrm{Cl}$ & $28.3-65.7$ & $0.1-17.2$ & $0.1-17.2$ & $0.8-22.1$ & $7.7-38.6$ & $0.8-22.1$ & $7.7-38.6$ \\
\hline \multicolumn{2}{|c|}{ p-value I-II } & $0.080^{\mathrm{a}}$ & $0.300^{c}$ & $0.300^{c}$ & $0.088^{c}$ & $0.357^{\mathrm{b}}$ & $1.000^{c}$ & $0.517^{b}$ \\
\hline \multirow{3}{*}{$\begin{array}{l}\text { III group } \\
(\mathrm{n}=30)\end{array}$} & Modulus & 9 & 0 & 0 & 2 & 4 & 4 & 9 \\
\hline & $\%$ & 30 & 0 & 0 & 7 & 13 & 13 & 30 \\
\hline & $95 \% \mathrm{Cl}$ & $14.7-49.4$ & - & - & $0.8-22.1$ & $3.8-30.7$ & $3.8-30.7$ & $14.7-49.4$ \\
\hline \multicolumn{2}{|c|}{ p-value I-III } & $0.920^{\mathrm{b}}$ & $1.000^{c}$ & $1.000^{c}$ & $0.088^{c}$ & $0.081^{c}$ & $0.236^{c}$ & $0.920^{c}$ \\
\hline \multicolumn{2}{|c|}{ p-value II-III } & $0.289^{b}$ & $0.50^{\circ c}$ & $0.500^{c}$ & $1.000^{c}$ & $0.731^{c}$ & $0.671^{c}$ & $0.549^{c}$ \\
\hline
\end{tabular}

High risk strains of HPV had the highest prevalence of viruses, and even though revealed differences in the frequency of occurrence were not statistically significant, it is impossible not to note a significantly higher infectious load in the I group compared with the control group and with group II (31\% vs. $13 \%$ and $20 \%$ respectively). The rest of the viruses (HSV, CMV) colonized cervical biotope of women from group II in insignificant amounts, and were not present at all in group I.
Combination of viruses + CPF (conditionally pathogenic flora) were rarely found in equal amounts in all of the groups $(6 \%-I, 7 \%-I I)$.

Summary data about the frequency of detection of microbial factor from endometrial biopsy in examined patients on the basis of culture research and PCR are shown in Table 4.

In general, the uterine cavity infection rate was $83 \%$ in women with $\mathrm{EP}, 73 \%$ - with MP, 77\% in healthy women. 
Among the pathogenic microbial agents in group I and group II, ureaplasma predominated (29\% and 27\%, respectively). From the endometrium of healthy women this infectious microorganism was isolated with almost the same frequency (30\%), however, the leading result belonged to Enterococci. Interestingly, the resident of colon microbiocenosis, Enterococcus faecalis, was detected in the endometrium of the representatives of the control group significantly more often than in those from group I and group II ( $43 \%$ vs. $11 \%$ and $17 \%$, respectively) $\left(p_{1-I I I}=0.001, p_{I I-I I I}=0.049\right)$. Given that this microorganism did not colonize the vaginal and cervical biotope of women surveyed, it can be assumed that the inclusion of Enterococcus into the microecology of the uterus cavity occurs by translocation through the wall of the colon. The essence of this mechanism lies in the activity of immunocompetent dendritic cells that provide active migration of bacteria from the colon lumen to mesenteric lymph nodes and from there into the bloodstream.

It is important to note that women from group I demonstrated significantly greater incidence of endometrial infection with Candida spp. than women from other groups $\left(p_{1-\mid I I}=0.012\right)$. For example, Candida spp. did not show in the endometrial samples of control groups and its occurrence in cohort with the MP turned out very rare ( $7 \%$ vs. $21 \%)$. Moreover, upon comparison of the intensity of colonization with this infectious microorganism in vaginal and uterine lining, the following tendency was revealed: this microorganism was isolated 1.5-2 times more often from the endometrium of women in groups I and II than in the vagina, but the difference was not statistically significant.

Among other representatives of CPF, high frequency of occurrence of Streptococcus spp. in the endometrium cannot go unnoticed: every fifth woman with EP (17\%), every eighth woman from the control group (13\%) and one in ten with MP $(10 \%)$. However, the same microorganism was found more frequently in the vagina: almost twice in group III (29\%), and one and a half times in group II (17\%) and 3\% more than in group I.

The rest of the microorganisms colonized endometrial habitat in insignificant small quantities.

High specific weight of the viruses is a distinctive feature of patients with EP (26\%). Contamination indicator of the endometrium with HSV type 1,2 and 6 in women of this group was significantly higher than in those from the control group $(17 \%$ vs. $0 \%)\left(p_{1-I I I}=0.016\right)$. The differences in the frequency of detection of the pathogen in the cervical canal and the uterine cavity were insignificant. As for the remaining infectious microorganisms, the opposite trend was observed: high risk HPV strains were more often detected in the cervical discharge than in the endometrium ( $31 \%$ vs. $6 \%)(p=0.0002)$.

The spectrum of viruses isolated from the endometrium of women with MP was much smaller in number and not significantly different from that in the control group.

\section{DISCUSSION OF THE RESULTS}

We conducted a comprehensive microbiological study and found an interesting peculiarity: the frequency of infection of the uterus cavity with CPF was rather high both in patients with EP and MP and in healthy women. This fact once again put forward several questions. What do we know about microecology of the uterine cavity? What does modern science imply in the very notion of physiology of endometrial biocenosis? And whether sterility of the uterus lining is an unshakable dogma?

\begin{tabular}{|c|c|c|c|c|c|c|c|c|c|c|}
\hline & & 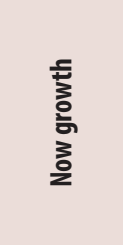 & 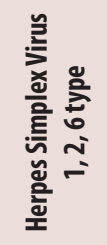 & 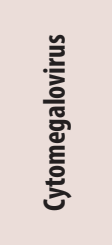 & $\begin{array}{l}\text { ․ㅡㄴ } \\
\text { 흘 } \\
\text { 롤 }\end{array}$ & 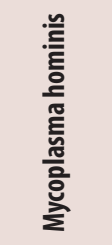 & 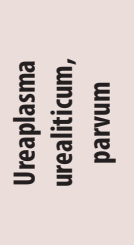 & 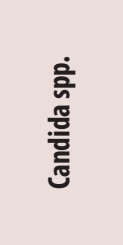 & 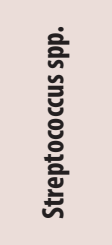 & 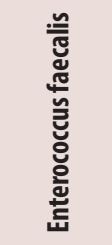 \\
\hline \multirow{3}{*}{$\begin{array}{l}\text { I group } \\
(n=70)\end{array}$} & Modulus & 12 & 12 & 2 & 4 & 2 & 20 & 15 & 12 & 8 \\
\hline & $\%$ & 17 & 17 & 3 & 6 & 3 & 29 & 21 & 17 & 11 \\
\hline & $95 \% \mathrm{Cl}$ & $9.2-28.0$ & $9.2-28.0$ & $0.4-9.9$ & $1.6-14.0$ & $0.4-9.9$ & $18.4-40.6$ & $12.5-32.9$ & $9.2-28.0$ & $5.1-21.3$ \\
\hline \multirow{3}{*}{$\begin{array}{l}\text { II group } \\
(\mathrm{n}=30)\end{array}$} & Modulus & 8 & 2 & 2 & 1 & 1 & 8 & 2 & 3 & 5 \\
\hline & $\%$ & 27 & 7 & 7 & 3 & 3 & 27 & 7 & 10 & 17 \\
\hline & $95 \% \mathrm{Cl}$ & $12.3-45.9$ & $0.8-22.1$ & $0.8-22.1$ & $0.1-17.2$ & $0.1-17.2$ & $12.3-45.9$ & $0.8-22.1$ & $2.1-26.5$ & $5.6-34.7$ \\
\hline \multicolumn{2}{|c|}{ p-value I-II } & $0.413^{b}$ & $0.219^{c}$ & $0.581^{c}$ & $1.000^{c}$ & $1.000^{c}$ & $1.000^{b}$ & $0.087^{c}$ & $0.543^{c}$ & $0.523^{c}$ \\
\hline \multirow{3}{*}{$\begin{array}{l}\text { III group } \\
(\mathrm{n}=30)\end{array}$} & Modulus & 7 & 0 & 4 & 0 & 4 & 9 & 0 & 4 & 13 \\
\hline & $\%$ & 23 & 0 & 13 & 0 & 13 & 30 & 0 & 13 & 43 \\
\hline & $95 \% \mathrm{Cl}$ & $9.9-42.3$ & - & $3.8-30.7$ & - & $3.8-30.7$ & $14.7-49.4$ & - & $3.8-30.7$ & $25.5-62.6$ \\
\hline \multicolumn{2}{|c|}{ p-value I-III } & $0.655^{b}$ & $0.016^{c}$ & $0.064^{c}$ & $0.313^{c}$ & $0.064^{c}$ & $0.920^{b}$ & $0.012^{c}$ & $0.771^{c}$ & $0.001^{b}$ \\
\hline \multicolumn{2}{|c|}{ p-value II-III } & $1.000^{b}$ & $0.492^{c}$ & $0.671^{c}$ & $1.000^{c}$ & $0.353^{c}$ & $1.000^{b}$ & $0.492^{c}$ & $1.000^{c}$ & $0.049^{b}$ \\
\hline
\end{tabular}

a - Pearson's chi-squared test;

b - Yates' chi-squared test;

'- Fisher's exact test 
Analysis of numerous literary sources on this issue gives conflicting information. On one hand, a number of domestic and foreign researchers who have studied the role of infectious factors in the genesis of EP and CE, unanimously postulate that the uterine cavity is sterile, and a cascade of inflammatory reactions arise when microorganisms penetrate the endometrium [15].

On the other hand, some scholars believe that the cyclical rejection of the endometrium provides the physiological antimicrobial protection of the uterus lining, which cannot be sterile due to continuous microbial influence from the lower genital tract [16].

The problem with most studies reviewed, in our opinion, was a strictly limited number of studied infectious microorganisms or small groups of control, which inevitably affected the "correct construction of" conclusions. Researchers viewed the results from healthy women as a norm, hence each study turned out to have its "own" norm.

According to modern views, the human body is densely populated with a wide variety of microbes and cannot function without them. In order to at least roughly systematize human symbionts, National Institute of Health of the United States launched a 5-year project "Human Microbiome" (2007). Its purpose was to identify all the species and quantitative composition of the microbiota of a healthy person by analyzing the DNA sequence of these organisms. To get an idea of the structure of a normal human microbiome, the researchers collected tissue samples from 15 sites on the body of 129 men and 18 sites of 113 women $[17,18]$. The reproductive tract was presented by the samples of vaginal fluid. Unfortunately, the project did not include endometrial microecology, but the fact that the results of this study have been used in more than 250 articles on human microbes proves the highest interest of the scientific community on this issue. And it allows us to treat a non-sterility as a norm.

Undoubtedly, the microbial composition of the vagina in the development of endometrial microbiocenosis plays an important role. The analysis of our data showed that the frequency of discharge and the intensity of the colonization of the vagina and the cervical canal with CPM in patients from surveyed groups generally corresponded with the index of microflora in the uterine cavity, there were only minor differences for certain types of microorganisms.

Enterococcus, that was found by us in the endometrium, is a representative of microbiota of the colon, may be a confirmation of the phenomenon of migration of microorganisms. It's now known that migration of microorganisms occurs hematogenously, lymphogenously or via intracellular transfer (translocation). It is proved that the latter mechanism secures various bacteria in the umbilical cord blood, amniotic fluid, placenta and bowel of healthy infants (which is contrary to the original postulate of fetus sterility), as well as in mother's breast milk [19]. Does this mechanism work outside the process of gestation?

Dendritic cells, macrophages are indispensable allies of endogenous microbiota. They not only present antigens to $\mathrm{T}$ and B lymphocytes, but also transport bacteria through the lymphatic system, building a path of transmission through translocation. In addition, macrophages are a constant cellular element of endometrial stroma, whose migration is under constant cyclic hormonal influence, and the highest concentration is observed just before menstruation due to the simultaneous decrease in the expression of estrogen and progesterone as a result of luteolysis. The fact that the number of macrophages in the endometrium under CE almost doubles suggests an idea: change in the microbiome of the endometrium is the cause or the consequence of a disease?

A limitation to this study was the fact that the selected pathogens in the endometrium of women surveyed were not correlated with their discovery in the colon. The lack of data on the qualitative and quantitative composition of the intestinal microbiota did not allow us to exclude disbiotic changes in the gastrointestinal tract, which in its turn could affect the results.

An imbalance in the ratio of proliferation/apoptosis is one of the pathogenetic mechanisms of origin and development of EP. Viruses are a recognized "genius" in this matter. Disabling apoptosis is possible due to the virus's ability to inactivate tumor-suppressor proteins that block natural cell death. By stimulating the growth of tumors the virus realizes its potential, because cell division also means doubling the genetic material of the virus. When a cell transits to effective and constant virus support, it provides a sufficient number of daughter viral particles as well as high contagiousness of infection.

The study of viruses has long been parallel to the study of the nature of cancer. HPV has been isolated from malignant tumors of virtually all organs except for heart and kidney. New studies keep suggesting the evidence that not only HPV has the carcinogenic potential in the cervical epithelium but also HSV type 2 [20]. The question on self-carcinogenic potential of HSV type 1 is yet to be solved.

Another interesting aspect is found in the modern scientific literature. It contains data on the relationship between formation of morulae and HPV infection of the tissue. Morulae are inflammatory accumulations of flat epithelial cells, a sign of squamous differentiation of the endometrium. These are not tumor cells yet, but intermediate cells that are found not only in adenocarcinoma, but also during benign endometrial processes such as hyperplasia, submucous myoma of uterus, senile transformation, IUD and chronic endometritis. According to various studies HPV has been found in 9.1 - 46\% cases of CE and endometrial hyperplasia, which suggests involvement of a virus in their pathogenesis [21].

This was an important point that our study strived to highlight.

Ourfindings showed the highest percentage of virus infection of the endometrium in women with EP. A comparative analysis of each type in the groups did not reveal statistically significant differences. However, the total number of HSV types 1, 2 and 6 significantly prevailed in this group of women.

Throughout the study, a clear trend was present: the more endometrium was compromised, the more frequently viruses were detected in it. Thus, HSV and HPV was not detected at all in healthy women, yet those diagnosed with micropoliposis demonstrated presence of the viruses 10 times more often, and those diagnosed with EP 23 times more often!

Specificity of infection process during penetration of a virus is that the immune system is under attack. The immune 
hypothyroidism is a significant aspect of the pathogenetic picture of a viral infection. On one hand, previously overloaded or improperly functioning immune system is not able to recognize and completely eliminate an infection, on the other hand, virus infestation can itself cause immunosuppression. Perhaps, in order to obtain reliable data, one must specify the nature of the immune response of women with a variety of viral agents, group them according to the obtained change and build a more extensive research.

Additionally, there is a relevant association of "HSV + HPV" and the question of the mutual influence of different types of viruses to this day remains open. Equally important is the fact that herpes infection is always systemic. Persisting in the nerve ganglia, the virus shows tropism towards many tissues of ecto- and endodermal origin. What exactly provokes it to appear in uterine mucosa is yet to be found. Our study did not find a similar pattern, the viruses in the uterine cavity were recorded as a monoculture or in the composition of bacterial and viral associations. It is quite possible that this dependence is a perspective research objective for the future more powerful studies.

In addition to viruses, the endometrium of women with EP was significantly more often populated by fungi of the genus Candida. There are three mechanisms found in the literature that describe how Candida can stimulate growth of tumors.

The first one is related to its ability to isolate specific Candida proteins (eg p43), that possess potent immune-suppressive properties and prevent from the struggle against an infectious aggressor. These proteins inhibit the activity of macrophages, NK-cells and cytotoxic T-lymphocytes, block the synthesis of antibodies that are informative for immunity with Blymphocytes, and thus reduce the antiviral defense.

The second mechanism lies in the fact that under the influence of Candida infection cytokine synthesis is broken, including IFN- $\gamma$ (the main protein chain in antiviral defense).

The third one is related to the ability of Candida to produce mycoestrogens that potentially enhances local hyperestrogenia and points to a possible role of this infectious microorganism in proliferation processes.

\section{CONCLUSIONS}

Thus, in the course of the study the following results were obtained:

3 EP and MP are a pathology that runs in the background of dysbiotic disorders in the vagina;

- Presence of microbial agents in endometrial tissue does not always indicate an inflammatory process;

3o conclusive evidence has been found on etiologic role of an infectious agent in the development of MP;

3 EP diagnosis often combines with herpes simplex virus and Candida;

3 Detection of representatives of intestinal microbiota in the endometrium suggests a possible role of dysbiotic changes of digestive tract in the uterine cavity infection;

3 Evaluation of concordance of infection in the cervical canal and the endometrium convinces in diverse predominance of microbial representatives with uneven occurrence in different niches.

In conclusion, it should be noted that microbiological examination of the endometrium is difficult to standardize. The transformation speed of microbial landscape does not always enable to trace its evolution even in normal endometrium. Therefore, in detection of CE and EP, microbiological diagnosis is still a "weak link". And the question of an infectious trigger in the genesis of these diseases remains rhetorical.

\section{REFERENCES / ЛITEPATYPA}

1. Hinckley, M.D., Milki, A.A.

"1000 office-based hysteroscopies prior to in vitro fertilization: feasibility and findings." JSLS 8.2 (2004): 103-107.

2. de Sa Rosa e de Silva, A.C., Rosa e Silva, J.C., et al.

"Routine office hysteroscopy in the investigation of infertile

couples before assisted reproduction." Journal of Reproductive Medicine 50 (2005): 501-6.

3. Spiewankiewicz, B., Stelmachow, J., Sawicki, W., et al.

"The effectiveness of hysteroscopic polypectomy in cases

of female infertility." Clinical and Experimental Obstetrics \& Gynecology 30 (2003): 23-5.

4. Richlin, S., Ramachandran, S., Shanti, A., et al.

"Glycodelin levels in uterine flushings and in plasma of patients with leiomyomas and polyps: implications for implantation."

Human Reproduction 17 (2002): 2742-7.

5. Ben-Nagi, J., Miell, J., Yazbek, J., et al.

"The effect of hysteroscopic polypectomy on the concentrations

of endometrial implantation factors in uterine flushings."

Reproductive BioMedicine Online 19.5 (2009): 737-44.

6. Maia, H., Maltez, A., Calmon, L., et al.

"Histopathology and steroid receptors in endometrial polyps of postmenopausal patients under hormonereplacement therapy."

Gynaecological Endoscopy 7.5 (2002): 267-72.

7. Mittal, K., Schwartz, L., Goswami, S., et al.

"Estrogen and progesterone receptor expression in endometrial polyps." International Journal of Gynecological Pathology 15

(1996): 345-8.

8. Maia, H., Maltez, A., Studart, E., et al.

"Ki67, BCl-2 and $\mathrm{p5} 3$ expression in endometrial polyps and in the normal endometrium during the menstrual cycle." BJOG: an International Journal of Obstetrics and Gynaecology 111.11 (2004): 1242-7.
9. Taylor, L., Jackson, T., Reid, J., et al.

"The differential expression of oestrogen receptors, progesterone receptors, BCl-2 and Ki67 in endometrial polyps." BJOG: an International Journal of Obstetrics and Gynaecology 110.9 (2003): 794-8.

10. Indraccolo, U., Di lorio, R., Matteo, M., et al. "The pathogenesis of endometrial polyps: a systematic semi-quantitative review." European Journal of Gynaecological Oncology 34.1 (2013): 5-22.

11. Erdemoglu, E., Guney, M., Karahan, N., Mungan, T.

"Expression of cyclooxygenase-2, matrix metalloproteinase-2 and matrix metalloproteinase-9 in premenopausal and postmenopausal endometrial polyps." Maturitas 59 (2008): 268-74.

12. Сухих, Г.Т., Шуршалина А.В.

Хронический эндометрит. - М.: ГЭОТАР-Медиа. - 2013. - 64 с. Sukhikh, G.T., Shurshalina, A.V.

Chronic endometritis. Moscow. GEOTAR-Media (2013): 64 p.

13. Cicinelli, E., Resta, L., Nicoletti, R., et al.

"Endometrial micropolyps at fluid hysteroscopy suggest the existence of chronic endometritis." Human Reproduction 20.5 (2005): 1386-9.

14. Resta, L., Palumbo, M., Rossi, R., et al.

"Histology of micropolyps in chronic endometritis."

Histopathology 60.4 (2012): 670-4.

15. Гомболевская, Н.А.

Современные возможности этиологической диагностики хронического эндометрита / Н.А. Гомболевская,

В.В. Муравьева, Л.А. Марченко и др. // Акушерство и гинекология. - 2012. - № 8. - С. 40-45.

Gombolevskaya, N.A., Muravyeva, V.V., Marchenko, L.A., et al.

"Modern possibilities of etiological diagnosis of chronic

endometritis." Obstetrics and Gynecology 8 (2012): 40-5.
16. Andrews, W.W., Goldenberg, R.L, Hauth, J.C, et al.

"Interconceptional antibiotics to prevent spontaneous preterm birth: a randomized clinical trial." American Journal of Obstetrics \& Gynecology 194.3 (2006): 617-23.

17. Integrated Microbial Genomes (IMG) system [Web-resource].

Available from: [https://img.jgi.doe.gov/]

18. Костин, И.Н

Значение и результаты международного

исследовательского проекта «Микробиом человека» /

И.Н. Костин, Л.Ю. Куванкина, Х.Ю. Симоновская //

StatusPraesens. - 2013. - № 5. - C. 9-15.

Kostin, I.N., Kuvankina, L.Y., Simonovskaya, H.U.

"The value and the results of the International Human

Microbiome Research Project." StatusPraesens 5 (2013): 9-15.

19. Рымашевский, А.Н.

Бактериальное приданое новорожденного /

А.Н. Рымашевский, Ю.Л. Набока, Э.Г. Свирава //

StatusPraesens. - 2015. - № 5. - C. 72-79.

Rymashevskiy, A.N., Naboka, Y.L., Svirava, E.G.

"The bacterial portion of newborn." StatusPraesens 5 (2015):72-9.

20. Zhao, Y., Cao, X., Zheng, Y., et al.

"Relationship between cervical disease and infection with human papillomavirus types 16 and 18 , and herpes simplex virus 1 and 2." Journal of Medical Virology 84.12 (2012): 1920-7. 21. Унанян, А.Л.

Роль сочетания ВПЧ-инфекции и хронического эндометрита в патогенезе злокачественных опухолей эндометрия /

А.Л. Унанян, И.С. Сидорова, Ю.М. Коссович и др. //

StatusPraesens. - 2012. - №3. - C. 23-26.

Unanyan, A.L., Sidorova, I.S., Kossovich, Y.M., et al.

"The role of the combination of HPV infection and chronic endometritis in the pathogenesis of endometrium cancer tumors." StatusPraesens 3 (2012): 23-6. 
T.F. Tatarchuk, MD, professor, corresponding member of the HAMS of Ukraine, deputy director for research work, chief of the Endocrine Gynecology Department, SI "IInstitute of Pediatrics, Obstetrics and Gynecology of the NAMS of Ukraine"

D.G. Herman, postgraduate student at the Endocrine Gynecology Department, SI "Institute of Pediatrics, Obstetrics and Gynecology of the NAMS of Ukraine"

Endometrial polyp is the most common structural abnormality of the mucous membrane of the uterus (endometrium) detected in unexplained infertility. Endometrial micropolyps are a hysteroscopic sign of chronic endometritis, detectable in $60 \%$ of women suffering from infertility. Both of the lesions provide an unfavorable environment for the endometrium receptivity and therefore may have common features in their etiopathogenesis.

Study objective: to study the composition of microbiota in the vagina, the cervix and the uterine cavity in women of reproductive age diagnosed with endometrial polyps and micropolyps.

Study design: the study involved 130 patients aged 18-35 years: 70 patients with endometrial polyps (group I), 30 patients with micropolyps (group II) and 30 patients of the control group (group III).

Study methods: group I and II were diagnosed by hysteroscopy with histological confirmation, endometrial samples from healthy women were obtained by aspiration biopsy. Test system "Femoflor" was used to study the quantitative composition of vaginal microbiota, bacteriological examination of the cervix and the endometrium was performed by PCR and by cultivating aerobic and anaerobic microorganisms on special growth media.

Study results: no statistically significant differences in the quantitative composition of vaginal microbiota have been identified in all study groups, the only changes recorded have been in the number of lactobacilli. The control group reported sufficient content of lactobacilli in $63 \%$ of women studied, the group I - 39\%, the group II - from $23 \%$. The cervical canal was sterile in $29 \%$ of women with polyps, $47 \%$ of women with micropolyps and $30 \%$ of healthy patients. The spectrum of pathogens isolated from the cervical canal was much narrower as opposed to the vagina and had no statistically significant differences between the groups. The frequency of the uterine cavity infection was $83 \%$ in women of group I, $73 \%$ in group II and $77 \%$ in group III. The endometrium of the patients from the control group has been seeded with noticeably more Enterococcus faecalis (43\% vs. $11 \%$ in group I and $17 \%$ in group II). Endometrial samples of women from group I were characterized by significantly higher detection of Candida spp. - 21\%, and herpes viruses type 1, 2, and 6 - 17\%. The spectrum of microorganisms isolated from the endometrium of women with micropolyps did not significantly differ from that in the control group. Evaluation of concordance of the vaginal and endometrial biotope in all groups has not shown any significant differences but in Enterococcus faecalis in the I group (0 vs. 11\%) and group III (0 to 43\%). When comparing cervical and endometrial biotope the only significant difference has been detected in the group of women with endometrial polyps and concerned herpes virus type 6 ( 0 vs $11 \%)$ as well as the high-risk strains of HPV (31\% vs. 6\%).

The limitations of this study: isolated endometrial pathogens were not correlated with the qualitative and quantitative composition of the gastrointestinal microbiota; further reliable data can be obtained from the detailed study of the nature of immune response in women with a variety of viral agents detected in the uterine cavity, as well as from classifying them according to the obtained results and building a more large-scale research.

Conclusions: endometrial polyps and micropolyps - a pathology that results from dysbiotic changes in the vagina. The presence of microbial agents in the uterine cavity is not always indicative of the inflammatory processes. No convincing evidence of the etiologic role of any infection in the micropolyps formation has been obtained. Women with endometrial polyps demonstrated higher content of Candida spp. and viruses.

Keywords: endometrial polyp, micropolyps, chronic endometritis, infertility, microbiota.

\section{ПОЛІПИ І МІКРОПОЛІПИ ЕНДОМЕТРІЯ. МІКРОБНИЙ ПЕЙЗАЖ ПОРОЖНИНИ МАТКИ ТА ЙОГО РОЛЬ В ЇХНЬОМУ ФОРМУВАННІ}

т. Ф. Татарчук, д. мед. н., професор, член-кор. НАМН України, заст. директора з наукової роботи, зав. відділенням ендокринної гінекології ДУ «ІПАГ НАМН України»

Д. Г. Герман, аспірант відділення ендокринної гінекології ДУ «ПАГ НАМН України»

Поліп ендометрія - найпоширеніша структурна аномалія слизової оболонки матки, яка зустрічається при ідіопатичному безплідді. Мікрополіпи ендометрія - гістероскопічна ознака хронічного ендометриту, що виявляється у $60 \%$ неплідних жінок. Ці обидва явища забезпечують несприятливе середовище для рецептивності ендометрія, а отже, можуть мати дещо спільне в своєму етіопатогенезі.

Мета дослідження: вивчити склад мікрофлори піхви, цервікального каналу та порожнини матки у жінок репродуктивного віку з поліпами і мікрополіпами ендометрія.

Дизайн дослідження: обстежено 130 пацієнток у віці 18-35 років: 70 пацієнток з поліпами ендометрія (I група), 30 - з мікрополіпами (II група) і 30 - контрольної групи (III група).

Методи дослідження: в основних групах діагноз було встановлено при гістероскопічному дослідженні і підтверджено гістологічно, у здорових жінок для отримання ендометріальних зразків використовували аспіраційну біопсію. Для вивчення кількісного складу вагінальної мікрофлори застосовували тест-систему «Фемофлор», бактеріологічне дослідження цервікального каналу та ендометрія проводили методом ПЛР і шляхом культивування аеробних і анаеробних мікроорганізмів на спеціальних поживних середовищах.

Результати дослідження: статистично значущих відмінностей в кількісному складі вагінальної мікрофлори в усіх досліджуваних групах виявлено не було, зміни зафіксовані тільки в кількості лактобацил. У контрольній групі достатній вміст лактобацил зареєстровано у 63\% жінок, у І групі - у 39\%, у II групі - у 23\%. Цервікальний канал був стерильним у $29 \%$ жінок із поліпами, у 47\% - 3 мікрополіпами та у $30 \%$ здорових пацієнток. Спектр патогенів, виділених із цервікального каналу, виявився значно вужчим у порівнянні з піхвою і не мав статистично значущих відмінностей в групах. Частота інфікування порожнини матки склала 83\% у жінок І групи, 73\% - II та 77\% - III групи. В ендометрії представниць групи контролю достовірно частіше висівали Enterococcus faecalis (43\% проти 11\% I групи і 17\% II групи). 3разки ендометрія жінок із поліпами характеризувалися значно більшою детекцією Candida spp. - 21\% та вірусів герпесу 1, 2 i 6 типу - 17\%. Спектр мікроорганізмів, виділених із ендометрія жінок з мікрополіпами, не відрізнявся від такого в контрольній групі. Оцінка конкордантності вагінального та ендометріального біотопу в групах продемонструвала значну різницю тільки стосовно Enterococcus faecalis в I групі (0 проти 11\%) та в III групі (0 проти 43\%). При порівнянні цервікального і ендометріального біотопу значуща різниця була зафіксована лише в групі жінок з поліпами ендометрія і стосувалася вірусу герпесу 6-го типу (0 проти 11\%) і ВПЛ високоонкогенних штамів (31\% проти 6\%).

0бмеження даного дослідження: виділені в ендометрії патогени не співвідносяться з якісним і кількісним складом кишкової мікробіоти; для отримання достовірних даних необхідно деталізувати характер імунної відповіді в жінок із різними вірусними агентами, виявленими в порожнині матки, групувати їх згідно з отриманими змінами і формувати більш масштабні дослідження.

Висновки: поліпи імікрополіпи ендометрія - патологія, що протікає на тлі дисбіотичних порушень в піхві. Наявність в порожнині матки мікробних агентів не завжди свідчить про запальний процес. Не отримано переконливих доказів етіологічної ролі будь-якої інфекції у формуванні мікрополіпів. У жінок із поліпами ендометрія порожнина матки характеризується більш високим вмістом Candida spp. і вірусів.

Ключові слова: поліп ендометрія, мікрополіп, хронічний ендометрит, безпліддя, мікробіоценоз.

\section{ПОЛИПЫ И МИКРОПОЛИПЫ ЭНДОМЕТРИЯ. МИКРОБНЫЙ ПЕЙЗАЖ ПОЛОСТИ МАТКИ И ЕГО РОЛЬ В ИХ ФОРМИРОВАНИИ}

Т. Ф. Татарчук, Д. мед. н., профессор, член-корр. НАМН Украины, зам. директора по научной работе, зав. отделением эндокринной гинекологии ГУ «ИПАГ НАМН Украины»

Д. Г. Герман, аспирант отделения эндокринной гинекологии ГУ «ИПАГ НАМН Украины»

Полип эндометрия - наиболее распространенная структурная аномалия слизистой оболочки матки, встречающаяся при необъяснимом бесплодии. Микрополипы эндометрия -

гистероскопический признак хронического эндометрита, выявляемого у 60\% женщин, страдающих бесплодием. Оба эти поражения обеспечивают неблагоприятную среду для рецептивности эндометрия, а следовательно, могут иметь нечто общее в своем этиопатогенезе.

Цель исследования: изучить состав микрофлоры влагалища, цервикального канала и полости матки у женщин репродуктивного возраста с полипами и микрополипами эндометрия.

Дизайн исследования: обследовано 130 пациенток в возрасте 18-35 лет: 70 пациенток с полипами эндометрия (I группа), 30 - с микрополипами (II группа) и 30 - контрольной группы (III группа).

Методы исследования: в основных группах диагноз был установлен при гистероскопическом исследовании и подтвержден гистологически, у здоровых женщин для получения

эндометриальных образцов использовали аспирационную биопсию. Для изучения количественного состава влагалищной микрофлоры использовали тест-систему «Фемофлор», бактериологическое исследование цервикального канала и эндометрия проводили методом ПЦР и путем культивирования аэробных и анаэробных микроорганизмов на специальных питательных средах.

Результаты исследования: статистически значимые отличия в количественном составе влагалищной микрофлоры во всех исследуемых группах выявлены не были, изменения зафиксированы только в количестве лактобацилл. В контрольной группе достаточное содержание лактобацилл зарегистрировано у $63 \%$ женщин, в I группе - у $39 \%$, во II группе - у 23\%. Цервикальный канал был стерилен у $29 \%$ женщин с полипами, у 47\% - смикрополипами и у $30 \%$ здоровых пациенток. Спектр патогенов, выделенных из цервикального канала, оказался значительно более узким по сравнению с влагалищем и не имел статистически значимых отличий в группах. Частота инфицирования полости матки составила 83\% у женщин I группы, 73\% - II и у 77\% - III группы. В эндометрии представительниц группы контроля достоверно чаще высевали Enterococcus faecalis (43\% против 11\% I группы и 17\% II группы). Эндометриальные образцы женщин с полипами эндометрия характеризовались значимо большей детекцией Candida spp. - 21\% и вирусов герпеса 1, 2 и 6 типа - 17\%. Спектр микроорганизм0в, выделенных из эндометрия женщин с микрополипами, значимо не отличался от такового в контрольной группе. Оценка конкордантности вагинального и эндометриального биотопа в группах показала значимые отличия только в отношении Еnterococcus faecalis в І группе (0 против 11\%) и в III группе (0 против 43\%). При сравнении цервикального и эндометриального биотопа значимая разница была зафиксирована только в группе женщин с полипами эндометрия и касалась вируса герпеса 6-го типа (0 против 11\%) и ВПЧ высокоонкогенных штаммов (31\% против 6\%).

Ограничения данного исследования: выделенные в эндометрии патогены не соотносили с качественным и количественным составом кишечной микробиоты; для получения достоверных данных необходимо детализировать характер иммунного ответа у женщин с различными вирусными агентами, выявленными в полости матки, группировать их согласно полученным изменениям и формировать более масштабные исследования.

Выводы: полипы и микрополипы эндометрия - патология, протекающая на фоне дисбиотических нарушений во влагалище. Наличие в полости матки микробных агентов не всегда свидетельствует о воспалительном процессе. Не получены убедительные доказательства этиологической роли какой-либо инфекции в формировании микрополипов. У женщин с полипами эндометрия полость матки характеризуется более высоким содержанием Candida spp. и вирусов. 